\title{
GENETIC VARIABILITY IN PROGENIES OF Eucalyptus grandis AND Eucalyptus urophylla FOR TOLERANCE TO HYDRIC DEFICIT
}

\author{
Mateus Chagas Andrade ${ }^{1}$, Leandro de Siqueira² ${ }^{2}$ Shinitiro Oda², Raimundo Nonato Medeiros², \\ Evandro Vagner Tambarussi ${ }^{1 *}$
}

\footnotetext{
${ }^{1}$ Midwestern State University, Department os Forestry, Irati, Paraná, Brasil - chagasa.mateus@gmail.com; tambarussi@gmail.com* ${ }^{2}$ Suzano Pulp and Paper Inc, Itapetininga, São Paulo, Brasil - 1siqueira@ suzano.com.br; shinitiro.oda@ gmail.com; rmedeiros@suzano.com.br
}

Received for publication: 07/11/2017 - Accepted for publication: 16/05/2018

\begin{abstract}
Genetic variability in progenies of Eucalyptus grandis and Eucalyptus urophylla for tolerance to hydric deficit. Information on the adaptation and genetic potential of Eucalyptus under water deficit conditions is necessary owing to the increasing cultivation of the genus in regions considered as "forest frontiers". Therefore, the present study aimed to estimate genetic variability, genotypic and phenotypic correlations, and estimated genetic gains in progenies of E. grandis and E. urophylla. Two progeny tests (TP1 and TP2) were performed in the municipality of Vila Nova dos Martirios (state of Maranhão, Brazil), in 30-month-old plants. The experiment was carried out using a randomized block design, with five replicates, nine plants/square plot, and 144 treatments in TP1 and 264 in TP2. Statistical analysis was performed and genetic parameters were estimated. Individual and within-progeny heritabilities were corrected using the kinship coefficient for each species. Genetic gains were low, ranging from 0.96 to $6.39 \%$ for E. grandis and 1.62 to $5.48 \%$ for E. urophylla. The diameter at breast height (DBH) showed a higher coefficient of genetic variation compared with the other measured characteristics, suggesting a higher potential for selection. High, positive, and significant correlations were observed between DBH and height $(\mathrm{H})$, indicating the possibility of obtaining gains based on a single characteristic. Heritability was considered low, thus directly influencing the selection gains, which were lower than those commonly reported in other studies. These findings provide important information for breeding programs in areas of forest expansion.
\end{abstract}

Keywords: Forest improvement, heritability, genetic correlation, Eucalyptus.

\section{Resumo}

Variabilidade genética em progênies de Eucliptus grandis $e$ Eucalyptus urophylla para tolerância ao déficit hídrico. Informações sobre adaptação e potencial genético de Eucalyptus às condições de déficit hídrico são necessárias devido à expansão territorial de cultivo do gênero, principalmente em regiões consideradas "fronteiras florestais". Portanto, a presente pesquisa objetivou estimar a variabilidade genética, correlações genotípicas e fenotípicas, herdabilidades e ganhos genéticos em progênies de E. grandis (TP1) e E. urophylla (TP2), avaliadas em dois testes de progênie no município de Vila Nova dos Martírios (MA) aos 30 meses de idade. O delineamento experimental utilizado foi realizado em blocos ao acaso, com cinco repetições, nove plantas por parcela quadrada, com 144 tratamentos no TP1 e 264 no TP2. Foram medidos os caracteres diâmetro a altura do peito (DAP) e altura (A). Os ganhos genéticos foram baixos, variando entre 0,96 e 6,39\% para E. grandis e 1,62 e 5,48\% para E. urophylla. O caráter DAP apresentou maior coeficiente de variação genético, apresentando maior potencial para seleção. Correlações altas, positivas e significativas foram encontras entre DAP (diâmetro a altura do peito, em $\mathrm{cm}$ ) e A (altura, em m), possibilitando obter-se ganhos a partir da seleção indireta em um único caráter. As herdabilidades foram baixas, portanto, influenciaram diretamente nos ganhos por seleção, os quais foram inferiores aos comumente obtidos em outros estudos. A presente pesquisa gerou informações importantes para os programas de melhoramento em áreas de expansão florestal.

Palavras-chave: Melhoramento florestal, herdabilidade, correlação genética, Eucalyptus.

\section{INTRODUCTION}

Brazil has great potential for the reforestation of Eucalyptus due to the different soil and climate types throughout its territory. Successive increases in the productivity of forests of the genus are due to the development of more productive and adapted genetic materials. Among the species that are prominent in productivity, Eucalyptus grandis W. Hill ex Maiden stands out for its potential for growth, adaptation, and flexibility to be used for various purposes. Eucalyptus urophylla S. T. Blake has been the main component species of hybrids when using E. grandis as one of the parents, because of its great potential for adaptation and rusticity. In this way, advances in breeding 
strategies of the genus, mainly of the species E. grandis and E. urophylla, have occurred as a definition of the best species to be cultivated and also the best provenances (ROCHA et al., 2007).

In regions currently considered "forest frontiers", such as the state of Maranhão, Brazil, it is necessary to select genotypes adapted to conditions in which water and nutrient scarcity is accentuated (REIS; PALUDZYSZYN FILHO, 2011). Thus, breeding programs should be established to obtain superior genotypes, enhancing trait such as tolerance to prolonged periods of drought, nutrient storage capacity, survival, and productivity.

In progeny tests, genetic parameters are estimated to aid the planning of breeding programs, as well as to provide data for selection strategies and thus maximize genetic gains in the trait of interest. Genetic parameters are based on the variability of traits of interest in the populations, thus determining the genetic potential of the material. In addition to estimates of genetic parameters, progeny tests provide important information for the determination of selection indexes, selection of breeders for hybrids, and adaptability assessments (ROCHA et al., 2007). Thus, the objectives of the present study were: i) to estimate the genetic variability; ii) to estimate the genotypic and phenotypic correlations between traits; iii) to estimate the expected gains with different intensities of selection; and iv) to correct the heritabilities based on the kin coefficient within the open-pollinated progenies of E. grandis and E. urophylla at 30 months of age, in two progeny tests installed in the municipality of Vila Nova dos Martírios, state of Maranhão, Brazil.

\section{MATERIAL AND METHODS}

\section{Experimental material}

Two tests of the open-pollinated progenies of E. grandis and E. urophylla (TP1 and TP2) from the Suzano Pulp and Paper Inc were carried out in the Santa Rosa Farm, in the municipality of Vila Nova dos Martírios, state of Maranhão, Brazil ( $5^{\circ} 12^{\prime}$ latitude $S$ and $47^{\circ} 37^{\prime}$ longitude $\mathrm{W}$, altitude of $95 \mathrm{~m}$ ). The climate of the region is warm and humid (Aw), with dry winters, annual average precipitation of $1,893 \mathrm{~mm}$, average annual temperature of $29.3^{\circ} \mathrm{C}$, Red-Yellow Latosol soil type, and flat to soft-wavy relief.

The progeny tests were installed in 2012 in a complete blocks design at random. TP1 was composed of 144 treatments (TP1), 97 progenies of E. grandis and 42 progenies of E. urophylla, while TP2 was composed of 264 treatments, 97 progenies of E. grandis, and 162 progenies of E. urophylla. Four hybrid clones between E. urophylla $\mathrm{x}$ E. grandis and one clone of E. urophylla var. platyphylla were used as controls in both tests. Progenies of E. grandis were from Atherton (Australia), while progenies of E. urophylla were from Flores Island and Timor (Indonesia).

Five replicates were used in square plots containing nine plants, with spacings of $3 \times 2 \mathrm{~m}$ among plants. For the two progeny tests, the individual quantitative traits of silvicultural importance - diameter at breast height (DBH), total height (A), and survival of individuals (SOB) - were evaluated and measured at 30 months of age. Traits were evaluated as percentages based on the counts of live plants in each plot in relation to the total number of initial plants.

\section{Analysis of variance (ANOVA)}

Analysis of variance for quantitative traits of individual plants was performed considering all the effects as random, except for the general mean, and using the following statistical model (Equation 1).

$$
Y_{i j k}=\mu+b_{i}+t_{j}+e_{i j}+d_{i j k}
$$

In which: $Y_{i j k}$ : phenotypic value of the $k^{\text {th }}$ observation within the plot, of the $j^{\text {th }}$ treatment, in the $i$ th repetition (block); $\mu$ : overall mean of the variable under analysis; $b_{i}$ : effect of the $i^{\text {th }}$ repetition; $t_{j}$ : effect of the $j^{\text {th }}$ treatment; $e_{i j}$ : experimental error regarding the $j^{\text {th }}$ treatment of the $i^{\text {th }}$ repetition; and $d_{i j k}$ : experimental error related to the $k^{\text {th }}$ individual, of the $j^{\text {th }}$ treatment, of the $i^{\text {th }}$ repetition.

Due to the effects of clones and species in the experiment, the source of treatment variation was decomposed into its respective effects, using the following statistical model (Equation 2).

$$
t_{j}=h_{c}+s_{a}+v_{l}
$$

In which: $t_{j}$ : effect of the $j^{\text {th }}$ treatment, $h_{c}$ : effect of the $c^{\text {th }}$ clone, $s_{a}$ : effect of the $a^{\text {th }}$ species, and $v_{l}$ : effect of Group 1.

Likewise, to obtain the variance portion of E. grandis and E. urophylla, the source of species variation was decomposed from the following model (Equation 3).

$$
s_{a}=p_{f}+q_{g}+n_{l \prime}
$$


In which: $s_{a}$ : effect of the $a^{\text {th }}$ species, $p_{f}$ : effect of the $f^{\text {th }}$ progeny of $E$. grandis; $q_{g}$ : effect of the $g^{\text {th }}$ progeny of E. urophylla; and $n_{l}$ : Group 2 effect.

Statistical analyses were performed in the program Statistical Analysis System 9.4 (SAS, 2015) by PROC GLM (General Linear Model). For the treatment effects, the LSMEANS (least squares means) instruction was used with the SLICE option, which combined the effects of treatment with the effects of groups, thus obtaining the effects of clones E. grandis and E. urophylla. The analysis of the significance of the genotypic effects was performed by applying the $\mathrm{F}$ test of the analyses of variance. The estimates of the variance components were obtained from the average squares of the treatment effects in function of their mathematical expectations. The estimated components were: $\sigma_{p}^{2}$ : variance of progenies of $E$. grandis; $\sigma_{q}^{2}$ : variance of $E$. urophylla progenies; $\sigma_{e}^{2}$ : error variance between; and $\sigma_{d}^{2}$ : error variance within.

\section{Estimates of genetic parameters}

Additive genetic variance $\left(\sigma_{A}^{2}\right)$ was estimated by two models: (i) assuming the open-pollinated progenies are from random crosses and, consequently, the kinship within the progenies $(\rho)$ and half-sib $(\rho=0.25)$; thus, $\sigma_{\mathrm{A}}^{2}=\sigma_{\mathrm{p}}^{2} / 0.25=4 \sigma_{\mathrm{p}}^{2}$; and (ii) assuming open-pollinated progenies as originating from the mixed breeding system, and thus assuming that a mixture of different kinships within progenies, in which $\rho$ of 0.42 is used for $E$. grandis, as reported by Miranda et al. (2013) and $\rho$ of 0.33 is used for E. urophylla, as estimated by Gaiotto et al. (1997). The coefficients of heritability and variation were estimated as follows: individual heritability in the restricted sense $\left(\hat{\mathrm{h}}_{\mathrm{i}}^{2}\right)$ by means of Equation 4, average heritability between progenies $\left(\hat{\mathrm{h}}_{\mathrm{m}}^{2}\right)$ by means of Equation 5 , and heritability within progenies $\left.\widehat{(h}_{d}^{2}\right)$ by means of Equation 6 .
(4)

$$
\hat{\mathrm{h}}_{\mathrm{i}}^{2}=\frac{\sigma_{\mathrm{A}}^{2}}{\sigma_{\mathrm{p}}^{2}+\sigma_{\mathrm{e}}^{2}+\sigma_{\mathrm{d}}^{2}}
$$

$$
\hat{h}_{m}^{2}=\frac{\sigma_{p}^{2}}{\sigma_{p}^{2}+\left(\sigma_{e}^{2} / b\right)+\left(\sigma_{d}^{2} / n b\right)}
$$

$$
\widehat{\mathrm{h}}_{\mathrm{d}}^{2}=\frac{(1-\rho) \sigma_{\mathrm{p}}^{2}}{\sigma_{\mathrm{d}}^{2}}
$$

In which: $b$ : number of repetitions; and $n$ : plants/plot.

The coefficient of additive genetic variation $\left(\widehat{C V}_{g i}\right)$ was estimated using Equation 7, the coefficient of genetic variation between progenies $\left(\widehat{C V}_{g}\right)$ using Equation 8, and the coefficient of environmental variation $\left(\widehat{C V}_{e}^{2}\right)$ using Equation 9.

$$
\begin{aligned}
& \widehat{C V}_{g i}(\%)=\frac{\sqrt{\sigma_{A}^{2}}}{\bar{m}} \cdot 100 \quad(8) \quad \widehat{C V}_{g}(\%)=\frac{\sqrt{\sigma_{g}^{2}}}{\bar{m}} \cdot 100 \quad \text { (9) } \quad \widehat{C V}_{e}(\%)=\frac{\sqrt{Q M E}}{\bar{m}} \cdot 100 \\
& \text { mean of the variable under analysis; and } Q M E: \text { mean square of error between. }
\end{aligned}
$$

In which: $\bar{m}$ : mean of the variable under analysis; and $Q M E$ : mean square of error between.

The relative coefficient of variation was estimated as described by Vencovsky and Barriga (1992) through Equation 10; to support the selection of the best progenies, the accuracy of progeny selection was estimated using Equation 11.

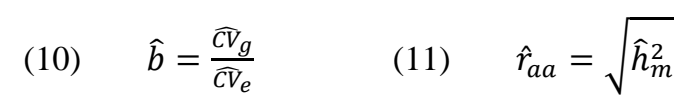

\section{Correlation between quantitative traits}

The genetic correlations $\left(\hat{r}_{g}\right)$ and phenotypic correlations $\left(\hat{r}_{p}\right)$ between DAP and total height were estimated from the mean individual squares, the sum of each pair of evaluated traits, and the mathematical expectations, thus obtaining the average products. Correlations for E. grandis and E. urophylla were estimated from Equation 12.

$$
\hat{r}_{g}=\frac{\widehat{\sigma}_{P x P y}}{\widehat{\sigma}_{P x}^{2} \widehat{\sigma}_{P y}^{2}}
$$

In which: $\hat{\sigma}_{P x P y}$ : cross-product of the traits $\mathrm{x}$ and $\mathrm{y}$; and $\hat{\sigma}_{P x}^{2}$ and $\hat{\sigma}_{P y}^{2}$ : genotypic variances between progenies for the traits $\mathrm{x}$ and $\mathrm{y}$, respectively.

Similarly, phenotypic correlations were determined. The cross products were estimated from the covariance analysis using the program SAS 9.4 (2015).

FLORESTA, Curitiba, PR, v. 48, n. 4, p. 543-552, out/dez. 2018 


\section{Gains with selection}

Estimates of selection gain were based on the selection between and within progenies ( $\Delta \widehat{\mathrm{G}} \mathrm{ed}$ ) (Equation 13).

$$
\Delta \widehat{\mathrm{G}} \mathrm{ed}=\Delta \widehat{\mathrm{G}} \mathrm{e}+\Delta \widehat{\mathrm{G}} \mathrm{d}
$$

In which: $\Delta \widehat{\mathrm{G}} \mathrm{e}$ : selection gain among progenies; and $\Delta \widehat{\mathrm{G}} \mathrm{d}$ : gain by selection within progenies.

The gain for progeny selection was estimated by Equation 14 and the selection gain within each progeny was estimated by Equation 15.

$$
\text { (14) } \Delta G_{e}=d_{s} h_{m}^{2} \quad(15) \quad \Delta G_{e}=i h_{d}^{2}+\sigma_{g}^{2}
$$

In which: $d_{s}$ : differential between progenies; and $i$ : intensity of selection.

Higher genotypes (highest values for each trait) were ordered in terms of their favourability for improvement, using the genotypic values estimated using best linear unbiased prediction (BLUP) and the program SAS 9.4 (2015). Based on this order, selection intensities of 10 and $30 \%$ were applied. The selection gains between and within the original mean of each trait were expressed as a percentage from Equation 16.

(16)

$$
\Delta \widehat{\mathrm{G}} \mathrm{ed} \%=(\Delta \widehat{\mathrm{G}} \mathrm{ed} .100) / \bar{X}
$$

In which: $\bar{X}$ : original average of each trait.

\section{RESULTS}

\section{Analysis of variance}

Significant differences were detected for the traits evaluated between progenies of E. grandis and E. urophylla in both tests (Table 1), indicating the existence of genetic variability and the possibility of obtaining gains from selection through the continuity of the breeding program species. The experimental coefficients of variation $\left(C V_{e} \%\right)$ were high (26.9 to $\left.39.9 \%\right)$.

Table 1. Results of analysis of variance with mean squares estimated for DBH (DAP) and height (A) in 30 months-old progenies of E. grandis and E. urophylla, in TP1 and TP2 progeny tests

\begin{tabular}{|c|c|c|c|c|c|}
\hline \multirow[b]{2}{*}{ Source of variation } & \multirow[b]{2}{*}{ Df } & \multicolumn{2}{|c|}{ TP1 } & \multicolumn{2}{|c|}{ TP2 } \\
\hline & & DBH (cm) & $\mathbf{A}(\mathbf{m})$ & DBH (cm) & $\mathbf{A}(\mathbf{m})$ \\
\hline Blocks & 4 & 94.1 & 74.5 & 11.7 & 136.9 \\
\hline Progenies & 143 & $32.6^{* *}$ & $41.3^{* *}$ & $24.1^{* * *}$ & $48.9^{* *}$ \\
\hline Clone & 4 & 27.8 & $95.8^{* *}$ & 16.6 & $58.1^{* * *}$ \\
\hline Species & 2 & $133.7^{* *}$ & $317.1^{* *}$ & $461.9^{* *}$ & $206.2^{* * *}$ \\
\hline E. grandis & 96 & $33.7^{* *}$ & $36.3^{* *}$ & $23.9^{* *}$ & $42.3^{* *}$ \\
\hline E. urophylla & 41 & $29.3^{* *}$ & $42.1^{* *}$ & $21.3^{* *}$ & $46.4^{* *}$ \\
\hline Error between & 572 & 15.4 & 17.3 & 10.9 & 16.4 \\
\hline Error within & 5760 & 14.1 & 14.4 & 9.6 & 14.3 \\
\hline$C \hat{V}_{e} \%$ & & 39.9 & 31.3 & 31.8 & 26.9 \\
\hline
\end{tabular}

Tabela 1. Resultados da análise de variância com quadrados médios estimados para os caracteres DAP e altura (A) nas progênies de E. grandis e E. urophylla aos 30 meses de idade, nos testes TP1 e TP2.

\section{Genetic parameters}

For E. grandis, the coefficient of genetic variation between progenies for DBH and A in both evaluated tests was of low magnitude (Table 2). The same behaviour was observed for E. urophylla progenies, which differed only in TP2, in which the coefficient of genetic variation for A (4.0\%) was higher than that for DBH (3.3\%). For each evaluated species, and in both tests, the coefficient of individual additive genetic variation was higher for DBH and A in relation to the coefficient of genetic variation between progenies. Again, DBH showed greater variability in both tests, and for 
both species evaluated. The individual heritabilities estimated for DBH and A, considering half-sib progenies, were relatively low for both species studied in both tests (from 0.03 to 0.12 ) (Table 2).

Considering a mixed breeding system for individual heritabilities, these were substantially reduced for $\mathrm{DBH}$ and $\mathrm{A}$ in both tests and species (from 0.02 to 0.07 ). Heritabilities within progenies presented behaviour similar to individual heritability; i.e., values were low and overestimated when the reproductive system of the species was not considered. In general, heritabilities within progenies were smaller than individual heritabilities. The average heritabilities between progenies for DBH and A were higher than those evaluated for both species, which were considered of medium magnitude (from 0.25 to 0.56 ).

Table 2. Estimates of genetic parameters for DBH (DAP) and height (A), assuming progenies of $E$. grandis and $E$. urophylla as half-sibs (MI), with mixed reproduction system (SM) in TP1 and TP2 progeny tests.

Tabela 2. Estimativas dos parâmetros genéticos para os caracteres DAP e A, assumindo progênies de E. grandis e E. urophylla como meios-irmãos (MI), originados de sistema misto de reprodução (SM) nos testes de progênie TP1 e TP2.

\begin{tabular}{|c|c|c|c|c|c|c|c|c|}
\hline \multirow{3}{*}{ Parameters } & \multicolumn{4}{|c|}{ E. grandis } & \multicolumn{4}{|c|}{ E. urophylla } \\
\hline & \multicolumn{2}{|c|}{ TP1 } & \multicolumn{2}{|c|}{ TP2 } & \multicolumn{2}{|c|}{ TP1 } & \multicolumn{2}{|c|}{ TP2 } \\
\hline & $\begin{array}{c}\text { DBH } \\
(\mathrm{cm})\end{array}$ & $\begin{array}{c}\mathbf{A} \\
(\mathbf{m})\end{array}$ & $\begin{array}{c}\text { DBH } \\
(\mathrm{cm})\end{array}$ & $\begin{array}{c}\mathbf{A} \\
(\mathbf{m})\end{array}$ & $\begin{array}{c}\text { DBH } \\
(\mathbf{c m})\end{array}$ & $\begin{array}{c}\mathbf{A} \\
(\mathbf{m})\end{array}$ & $\begin{array}{c}\text { DBH } \\
(\mathrm{cm})\end{array}$ & $\begin{array}{c}\mathbf{A} \\
(\mathbf{m})\end{array}$ \\
\hline$\hat{h}_{i}^{2} \quad(\mathrm{MI})$ & 0.12 & 0.12 & 0.03 & 0.04 & 0.04 & 0.07 & 0.04 & 0.08 \\
\hline$\hat{h}_{d}^{2}(\mathrm{MI})$ & 0.09 & 0.09 & 0.03 & 0.03 & 0.03 & 0.05 & 0.03 & 0.06 \\
\hline$\hat{h}_{i}^{2}(\mathrm{SM})$ & 0.07 & 0.07 & 0.02 & 0.03 & 0.02 & 0.05 & 0.03 & 0.02 \\
\hline$\hat{h}_{d}^{2}(\mathrm{SM})$ & 0.04 & 0.04 & 0.01 & 0.02 & 0.02 & 0.04 & 0.02 & 0.04 \\
\hline$\hat{h}_{m}^{2}$ & 0.56 & 0.54 & 0.25 & 0.31 & 0.30 & 0.40 & 0.31 & 0.46 \\
\hline$C \hat{V}_{g i} \%$ & 10.2 & 7.8 & 4.7 & 4.41 & 7.0 & 6.8 & 5.7 & 6.9 \\
\hline$C \hat{V}_{g} \%$ & 6.6 & 5.1 & 3.1 & 2.86 & 4.0 & 3.9 & 3.3 & 4.0 \\
\hline$\hat{r}_{a a}$ & 0.75 & 0.74 & 0.50 & 0.55 & 0.54 & 0.63 & 0.55 & 0.68 \\
\hline$\hat{b}$ & 0.17 & 0.16 & 0.10 & 0.11 & 0.10 & 0.13 & 0.10 & 0.15 \\
\hline
\end{tabular}

In which: $\hat{h}_{i}^{2}$ : individual heritability in the narrow sense; $\hat{h}_{d}^{2}$ : heritability within progenies; $\hat{h}_{m}^{2}$ : average heritability between progenies; $\widehat{C V}_{g l} \%$ : coefficient of individual additive genetic variation; $\widehat{C V}_{g} \%$ : coefficient of genetic variation between progenies; $\hat{r}_{a a}$ : accuracy in progeny selection; and $\hat{b}$ : coefficient of relative variation.

The relative coefficients of variation $(\hat{b})$ estimated for both species were considered low (from 0.10 to 0.17 ). The DBH evaluated in TP1 was considered to have greater potential for selection according to this parameter. The DBH and A traits of E. grandis presented the highest levels of accuracy in TP1 (0.75 and 0.74 , respectively), indicating that selection based on this trait can be performed with greater accuracy and precision.

\section{Genotypic and phenotypic correlations}

Genotypic $\left(\hat{r}_{g}\right)$ and phenotypic $\left(\hat{r}_{p}\right)$ correlations between DBH and A presented high values (Table 3$)$ in both progeny tests. The highest genotypic correlations were obtained in TP2 for E. grandis (0.96) and E. urophylla (0.99). The genotypic correlations in the TP1 test for E. grandis (0.88) and E. urophylla (0.86) were lower than the correlations in TP2. The was no marked variation in phenotypic correlations between traits and the progeny test, which remained similar with values from 0.85 to 0.87 . The highest phenotypic correlation was observed for E. urophylla, which was higher in TP2.

Table 3. Genotypic $\left(\hat{r}_{g}\right)$ and phenotypic $\left(\hat{r}_{p}\right)$ correlations between DBH (DAP) and height (A) in 30 months-old progenies of E. grandis and E. urophylla, in TP1 and TP2 progeny tests.

Tabela 3. Correlações genotípicas $\left(\hat{r}_{g}\right)$ e fenotípicas $\left(\hat{r}_{p}\right)$ entre DAP e A em progênies de E. grandis e E. urophylla aos 30 meses de idade, nos testes de progênie TP1 e TP2.

TP1 TP2

FLORESTA, Curitiba, PR, v. 48, n. 4, p. 543-552, out/dez. 2018

Andrade. M. C. et.al.

ISSN eletrônico 1982-4688 


\begin{tabular}{ccccccc}
\cline { 5 - 6 } \cline { 5 - 6 } & E. grandis & E. urophylla & & E. grandis & E. urophylla \\
\hline$\hat{r}_{g}$ & $0.88^{*}$ & $0.86^{*}$ & & $0.96^{*}$ & $0.99^{*}$ \\
$\hat{r}_{p}$ & $0.86^{* *}$ & $0.85^{* *}$ & & $0.86^{* *}$ & $0.87^{* *}$ \\
\hline
\end{tabular}

** Significant by t test at $1 \%$ probability; ${ }^{*}$ Significant by t test at $5 \%$ probability.

\section{Selection gains between and within progenies}

Estimated gains under a mixed breeding system were lower than those commonly obtained for the species evaluated in both progeny tests. There was variation in the obtained gains between species and progeny tests (Table 4). The genetic gains obtained by selecting between and within progenies for E. grandis were higher than the gains obtained for E. urophylla in both progeny tests. These gains ranged from 0.96 to $6.39 \%$ for $E$. grandis and from 1.62 to $5.48 \%$ for E. urophylla. The highest gains for E. grandis were obtained in TP1, which were higher than those obtained when using a $10 \%$ selection intensity for DBH and A in both tests. With $10 \%$ selection, A presented the greatest gains among all traits. The estimated selection gains between and within progenies of E. urophylla behaved similarly to those obtained for E. grandis; i.e., trait A presented the highest percentage of gains and intensity of selection at $10 \%$ and allowed greater gains with the selection. The estimated gains for selection among progenies (GSe) were higher than those obtained by progeny selection (GSd).

Table 4. Estimates of genetic gains by selection among and within 30 months-old progenies of E. grandis and E. urophylla, considering a mixed reproduction system for the DBH (DAP) and height (A), in TP1 and TP2 progeny tests.

Tabela 4. Estimativas de ganhos genéticos pela seleção entre e dentro em progênies (\%) de E. grandis e E. urophylla aos 30 meses de idade, considerando sistema misto de reprodução para os caracteres DAP e A, nos testes de progênies TP1 e TP2.

\begin{tabular}{|c|c|c|c|c|c|c|c|c|c|}
\hline \multirow{3}{*}{ Teste } & \multirow{3}{*}{$\begin{array}{c}\text { Gains from } \\
\text { selection }\end{array}$} & \multicolumn{4}{|c|}{ E. grandis } & \multicolumn{4}{|c|}{ E. urophylla } \\
\hline & & \multicolumn{2}{|c|}{ DBH (cm) } & \multicolumn{2}{|c|}{$\mathbf{A}(\mathbf{m})$} & \multicolumn{2}{|c|}{ DBH (cm) } & \multicolumn{2}{|c|}{$\mathbf{A}(\mathbf{m})$} \\
\hline & & $\mathrm{i}=10 \%$ & $\mathrm{i}=\mathbf{3 0 \%}$ & $\mathrm{i}=10 \%$ & $\mathrm{i}=\mathbf{3 0 \%}$ & $\mathrm{i}=10 \%$ & $\mathrm{i}=\mathbf{3 0 \%}$ & $\mathrm{i}=10 \%$ & $\mathrm{i}=\mathbf{3 0 \%}$ \\
\hline \multirow{3}{*}{$\bar{E}$} & GSd & 0.49 & 0.33 & 0.39 & 0.26 & 0.15 & 0.10 & 0.25 & 0.16 \\
\hline & GSe & 4.39 & 4.15 & 6.01 & 4.08 & 2.88 & 1.52 & 3.78 & 2.45 \\
\hline & $\mathrm{GSd}+\mathrm{GSe}$ & 4.88 & 4.48 & 6.39 & 4.33 & 3.03 & 1.62 & 4.02 & 2.61 \\
\hline \multirow{3}{*}{ 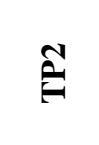 } & GSd & 0.06 & 0.04 & 0.08 & 0.66 & 0.13 & 0.09 & 0.31 & 0.20 \\
\hline & GSe & 1.73 & 0.92 & 2.94 & 2.11 & 3.40 & 2.30 & 5.17 & 3.25 \\
\hline & $\mathrm{GSd}+\mathrm{GSe}$ & 1.79 & 0.96 & 3.04 & 2.78 & 3.53 & 2.39 & 5.48 & 3.45 \\
\hline
\end{tabular}

In which: GSd: selection gain within progenies; GSe: selection gain among progenies; GSd+GSe: selection gain among and within progenies; and I: selection intensities.

\section{Growth and survival averages}

The mean DBH and A for E. grandis were similar to those observed for E. urophylla (Table 5). The growth of DBH and A in some progenies was superior to that of the clones used as controls in both tests. The progenies that showed higher averages in relation to the controls were those of $E$. grandis, for both evaluated traits, particularly the percentage of $E$. grandis in TP2, with $56.7 \%$ of the progenies superior to the controls for the DBH. The percentages of surviving E. grandis and E. urophylla in both progeny tests were of medium magnitude.

In TP1, the survival of E. grandis and E. urophylla at 30 months of age was 47.3 and $42.7 \%$, respectively, whereas that of the controls (clones) was $78.6 \%$, indicating better survival adaptation to the environment. In TP2, the survival of tested materials was higher than that of TP1. Progenies of E. grandis presented survival of $61.3 \%$, while that of E. urophylla was $60.3 \%$. The controls presented better adaptation to the environmental conditions, since the survival of these materials was $94.2 \%$. In both tests, greater survival of $E$. grandis was observed in relation to $E$. urophylla. TP2 controls presented superior survival when compared with TP1 controls.

Table 5. Percentage (\%) of E. grandis and E. urophylla progenies with mean DBH (DAP) and height (A) above average for 30 months-old clones (controls), in TP1 and TP2 progeny tests.

Tabela 5. Percentual (\% acima) de progênies de E. grandis e E. urophylla com médias de DAP e A superiores à média dos clones (testemunhas) aos 30 meses de idade, nos testes de progênie TP1 e TP2.

\begin{tabular}{ccccccc}
\hline Teste & Mean clones & E. grandis & E. urophylla & Mean clones & E. grandis & E. urophylla \\
\hline DBH $(\mathbf{c m})$ & \% above & \% above & A $(\mathbf{m})$ & $\%$ above & $\%$ above \\
\hline
\end{tabular}




\begin{tabular}{lllllll} 
TP1 & 10.3 & 30.9 & 16.7 & 14.6 & 12.4 & 7.1 \\
TP2 & 10.2 & 56.7 & 15.2 & 15.4 & 13.4 & 9.3 \\
\hline
\end{tabular}

\section{DISCUSSION}

\section{Analysis of variance}

The coefficient of experimental variation $\left(\widehat{C V}_{e} \%\right)$ in the tests was high when compared with that reported in other studies for the same species (MORAES et al., 2014a). It is possible that these results were due to the large number of treatments tested in both trials (144 and 264 for TP1 and TP2, respectively) and, consequently, the high soil heterogeneity in both progeny tests, indicating low local control.

\section{Genetic parameters}

The superiority of the genetic variation coefficient $\left(\widehat{C V}_{g} \%\right)$ for the A trait in E. urophylla in relation to DBH should not be immediately understood as determinant to be used in the selection. One should consider the greater ease of measuring DBH compared with A. In this way, the potential use of DBH in selection is greater. The coefficient $\left(\widehat{C V}_{g} \%\right)$ is considered to be a parameter of great importance for the continuity of breeding programs, since it allows additional gains in selection within progenies (SEBBENN et al., 1999). The superiority of the coefficient of individual additive genetic variation $\left(\widehat{C V}_{g i} \%\right)$ on the $\widehat{C V}_{g} \%$ was also verified by Moraes et al. (2014a), in addition to the greater variability presented by DBH in both tests and for the evaluated species. Therefore, DBH is the most suitable characteristic for the selection of materials in breeding programs.

The low heritabilities obtained assuming the progenies as half-sibs (MI) demonstrate low genetic control for the traits, directly influencing the gains expected from selection. According to Resende (1995), values between 0.01 and 0.15 are considered low for heritability. Consistent with our results, Sato et al. (2007) studied E. resinifera and obtained low individual and within-progeny heritabilities for DBH and $\mathrm{A}$ at 21 years due to low genetic control.

The reduction of individual heritabilities, considering the mixed breeding system (SM) in relation to the heritabilities obtained and assuming the progenies as half-sibs (MI), indicates that it has overestimated at the level of plants when neglecting the relationship between progenies and within the plots, directly affecting estimates of genetic gains (MIRANDA et al., 2013). Therefore, consistent with the hypothesis that ignores the possibility of inbreeding and occurrence of different kinships within the progenies and assuming these as half-sibs, Bush et al. (2011) studied E. cladocalyx and found that losses in genetic gain may occur if the additive genetic variance is not corrected from a kinship level, especially when levels of inbreeding vary among progenies. The same overestimate was found for heritabilities within progenies when the reproductive system (SM) of the species was not considered. Other studies have reported similar results (MACEDO et al., 2013).

Considering the low magnitude of individual and within-progeny heritabilities, it is important to evaluate the estimates of gains using the average selection among progenies, since these were of medium magnitude. However, similarly, individual and average heritabilities between progenies were low compared with those reported in other studies (ROCHA et al., 2007; MORAES et al., 2014a).

The relatively low coefficients of variation $(\hat{b})$ found in the present study suggest that environmental factors influenced the two progeny tests, demonstrating low genetic control for the traits evaluated. The greater the value of $\hat{b}$, the greater the genetic control of the phenotype, thus contributing directly to the estimated gains obtained with selection (VENCOVSKY; BARRIGA, 1992).

As well as the other parameters estimated in this study, such as the selection of progenies, which represent a relation between the genotypic value and the actual genotypic value and indicate the accuracy of the genotypic variance from the phenotypic variance of the traits (MORAES et al., 2014b), were found to be lower or average for the traits evaluated in the two progeny tests, when compared with studies of the same species (SOUZA et al., 2011).

\section{Genotypic and phenotypic correlations}

The high values obtained for genotypic and phenotypic correlations between DBH and A indicate that it may be possible to select superior individuals from both traits. Even the lower values for genotypic correlations obtained in TP1 compared with TP2 are considered to have potential for selection. Moraes et al. (2014a) obtained similar genotypic correlations in E. dunnii, E. saligna, and hybrid clones of the genus Eucalyptus and Corymbia for DBH and A at ages close to 30 months, as shown in this study. Similarity in the phenotypic correlations between traits and the progeny test indicates that selection based on this correlation allows the safe selection of traits for use as a reference to select individuals. 


\section{Selection gains}

The substantial reduction in selection gains, considering the mixed reproduction system, can be explained by the direct influence of the low $C V_{g} \%$ and low $\hat{h}_{i}^{2}, \hat{h}_{d}^{2}$ and $\hat{h}_{m}^{2}$ obtained in this study. Considering the progenies as half-brothers (MI) originating from a mixed breeding system (SM), the highest estimated gains with the $10 \%$ selection intensity were obtained for the A trait. However, it is preferable to select the best individuals through $\mathrm{DBH}$, due to the high genetic and phenotypic correlations found between DBH and A, and the ease and accuracy of measuring this characteristic (MACEDO et al., 2013). The highest genetic gains were obtained for a lower intensity of selection $(10 \%)$ due to the lower number of individuals selected, raising the selected population mean.

\section{DAP means, height, and survival}

The mean values for DBH and A were satisfactory, and were consistent with ages close to the same species (MORAES et al., 2014b). The superiority of growth for DBH and A in E. grandis progenies relative to the clones used as controls was satisfactory for the selection of superior individuals and the continuity of the breeding program. However, to select these materials, the superiority of $E$. urophylla progenies should be considered, even if they present a lower percentage compared with $E$. grandis, thus maximizing gains for both evaluated tests.

The survival of the individuals evaluated may have been influenced by the effects of the water deficit. The effects of water deficit depend on their intensity and duration, but mainly on the genetic capacity of plants to withstand the influence of the environment. Therefore, the support and adaptation capacity of the progenies evaluated reflects directly on the growth and development variations found. The percentage survival obtained for E. grandis and E. urophylla is evidence of the strong effect of the environment on the adaptability and development of progenies in a region with marked water deficit, such as the region of the study, resulting in poor adaptation to this type of climate. Oda et al. (1986) reported this in relation to the introduction of species and provenances of Eucalyptus, also in the state of Maranhão, Brazil. Those authors obtained an average survival of $88.3 \%$ due to the water deficit period. Therefore, compared with the results of Oda et al. (1986), our results revealed a greater impact of environmental factors besides water deficit, such as pests and diseases (personal information) on the evaluated progenies.

\section{CONCLUSION}

- Analysis of variance revealed genetic variability between and within the progenies of E. grandis and E. urophylla for $\mathrm{DBH}$ and height, confirming the potential of genetic gain through selection.

- The high genetic and phenotypic correlations found between DBH and height suggest the possibility of obtaining gains from selection, using DBH as a reference.

- Greater genetic gains are obtained through less intense selection between and within progenies.

- When the mixed breeding system is neglected, individual and within-progeny heritability is overestimated.

\section{ACKNOWLEDGMENTS}

We thank Suzano Pulp and Paper Inc for concession of experimental data for this study. We also thank $\mathrm{PhD}$ Bruna Mendes de Oliveira for her contribution to this study.

\section{REFERENCES}

BUSH, D.; KAIN, D.; MATHESON, C.; KANOWSKI, P. Marker-based adjustment of the additive relationship matrix for estimation of genetic parameters - an example using Eucalyptus cladocalyx. Tree Genetics \& Genomes, v.7, p. 23-35, 2011.

GAIOTTO, F. A.; BRAMUCCI, M.; GRATAPAGLIA, D. Estimation of outcrossing rate in breeding population of Eucalyptus urophylla with dominant RAPD and AFLP markers. Theoretical and Applied Genetics, Stuttgart, v. 95, p. 842-849, 1997.

MACEDO, H. R.; FREITAS, M. L. M.; MORAES, M. L. T.; ZANATA, M.; SEBBENN, A. M. Variação, herdabilidade e ganhos genéticos em progênies de Eucalyptus tereticornis aos 25 anos de idade em Batatais-SP. Scientia Forestalis, Piracicaba, v. 41, n. 100, p. 533-540, 2013.

MIRANDA, A. C.; MORAES, M. L. T.; TAMBARUSSI, E. V.; FURTADO, E. L.; MORI, E. S.; SILVA, P. H. M.; SEBBENN, A. M. Heritability for resistance to Puccinia psidii Winter rust in Eucalyptus grandis Hill ex Maiden in Southwestern Brazil. Tree Genetics \& Genomes, v.9, p. 321-329, 2013. 
MORAES, C. B.; FREITAS, T.C.M.; PIERONI, G.B.; RESENDE, M.D.V.; ZIMBACK, MORI, E.S. Estimativas de parâmetros genéticos para seleção precoce de clones de Eucalyptus para região com ocorrência de geadas. Scientia Forestalis, Piracicaba, v.42, n. 102, p. 219-227, 2014a.

MORAES, C. B.; BRIZOLLA, T. F.; TEIXEIRA, L. G.; ZIMBACK, L.; TAMBARUSSI, E. V.; CHAVES, R.; MORAES, M. L. T. de.; MORI, E. S. Estimativas dos parâmetros genéticos para seleção de árvores de Eucalyptus. Scientia Forestalis, Piracicaba, v. 42, n. 104, p. 623-629, 2014 b.

ODA, S.; FERREIRA, J. E. M.; KROGH, H. J. O.; MENCK, A. L. M.; KALIL, M. L. P. Introdução de espécies/procedências de Eucalyptus na região sub-úmida do estado do Maranhão. Revista IPEF, Piracicaba, n.34, p. 57-61, 1986.

REIS, C.A.F.; PALUDZYSZYN FILHO, E. Estado da arte de plantios com espécies de interesse para o Mato Grosso. Colombo: Embrapa Florestas, 2011. 63 p. (Série Documentos).

RESENDE, M. D. V. Delineamento de experimentos de seleção para maximização da acurácia seletiva e do progresso genético. Revista Árvore, v. 19, n. 4, p. 479-500, 1995.

ROCHA, M. G. B.; PIRES, I. E.; ROCHA, B. R.; XAVIER, A.; CRUZ, C. D. Seleção de genitores de Eucalyptus grandis e de Eucalyptus Urophylla para produção de híbridos interespecíficos utilizando REML/BLUP e informação de divergência genética. Revista Árvore, v.31, n.6, p.977-987, 2007.

SAS Institute Inc. SAS/IML® 14.1 User's Guide. Cary, NC: SAS Institute Inc. 2015.

SATO, A. S.; SEBBENN, A. M.; MORAES, E.; ZANATTO, A. C. S.; FREITAS, M. L. M. Seleção dentro de progênies de Eucalyptus resinífera aos 21 anos de idade em Luiz Antônio - SP. Rev. Inst. Flor., São Paulo, v. 19, n. 1, p.93-100, 2007.

SEBBENN, A. M.; SIQUEIRA, A. C. M. F.; KAGEYAMA, P. Y.; DI DIO JUNIOR, O. J. Variação genética entre e dentro de populações de amendoim - Pterogyne nitens. Scientia Forestalis, Piracicaba, n. 56, p. 29-40, 1999.

SOUZA, C. S. de; FREITAS, M. L. M.; MORAES, M. L. T. de; SEBBENN, A. M. Estimativas de parâmetros genéticos para caracteres quantitativos em progênies de polinização aberta de Eucalyptus urophylla. Floresta, Curitiba, v. 41, n. 4, p.847-856, 2011.

VENCOVSKY, R. BARRIGA, P. Genética biométrica no fitomelhoramento. Ribeirão Preto: Sociedade Brasileira de Genética, 1992. 406p.

FLORESTA, Curitiba, PR, v. 48, n. 4, p. 543-552, out/dez. 2018

Andrade. M. C. et.al.

ISSN eletrônico 1982-4688 